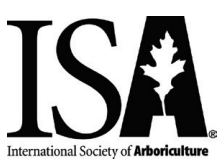

Arboriculture \& Urban Forestry 2017. 43(2):49-54

\title{
Does Modulus of Elasticity Vary Due to Dormancy and Temperature?
}

\author{
Gregory Dahle, Aaron Carpenter, David DeVallance, and Mo Zhou
}

\begin{abstract}
The Intergovernmental Panel on Climate Change states with high confidence that extreme climactic events pose high risks on services such as electric service grids. Some of the extreme events will likely take place earlier in autumn, before deciduous trees complete the process of becoming dormant. The presence of leaves in a transitional season-before leaf drop (pre-dormant)-can be of concern if an unseasonal snow or ice storm occurs, as compared to after leaf drop (dormant).

Researchers harvested stump sprouts and measured the flexural modulus of elasticity $(E)$ of wood to determine if it varies with seasonality (pre-dormant versus dormant) and with temperature (frozen $-6.7^{\circ} \mathrm{C}$ versus warm $21.1^{\circ} \mathrm{C}$ ) using a universal load press. While dormant sprouts (warm and cold) had higher average flexural elasticity than the warm pre-dormant sprouts, they were not statistically different than the cold pre-dormant sprouts. As such, it does not appear that the modulus of elasticity differs as trees enter dormancy. Surely, the presence of leaves will increase the bending moment that may lead to an increase in failure, but the slight increase in elasticity as trees enter dormancy should not reduce the likelihood of watersprouts undergoing significant bending during a snow or ice storm.

Key Words. Biomechanics; Climate Change; Dormancy; Flexural Elasticity; Modulus of Elasticity; Northern Red Oak; Quercus rubra; Temperature; Utility Arboriculture.
\end{abstract}

The Intergovernmental Panel on Climate Change states with high confidence that there is an increased risk in intensity and frequency of extreme climactic events due to global climate change (Field et al. 2014), leading to increased property damage as well as power outages that are wider spread and longer in duration in the near future (Field et al. 2012; Field et al. 2014). Trees are often subjected to large amounts of bending forces during the annual dormant period, attributable to wind throw (Valinger et al. 1995; Harris et al. 2004) and mechanical loading thought to be higher due to static loading from snow and ice coupled with dynamic loading (Valinger et al.1995). These higher mechanical loading events have been evident in the two successive years of early snowstorms in the eastern United States-2011 October nor'easter, and Super Storm Sandy in October 2012. These storms damaged trees in the forest and within major urban population centers, leaving hundreds of thousands of people without electrical service for days.
If early snowstorms or ice storms occur before deciduous trees are dormant, the overall loading event will be magnified. In temperate zones, deciduous trees often enter a dormant stage associated with leaf senescence (Kozlowski and Pallardy 1997). Leaf senescence occurs in autumn in the Northern Hemisphere when the weather is changing, and coincides with the possibility of an early snow event or ice storm. The presence of leaves in deciduous trees will likely lead to more failures (Cannell and Morgan 1989; Dahle et al. 2014). Some trees, which have been indiscriminately topped or are growing in electrical utility rights-of-way, have been subjected to lineclearance operations that result in the development of numerous watersprouts that are composed of juvenile wood with lower material properties (Dahle et al. 2006; Dahle and Grabosky 2010). In addition to a possible branch rupture, watersprouts could also bend excessively and come into contact with the energized power line, resulting in a power outage.

Flexural modulus of elasticity is a measurement of the resistance of a material to elastic deforma- 
tion when a bending type force is applied, within the linear portion of the stress-strain diagram. Generally, lower values for $E$ equate to high flexibility (Hibbeler 2005), and higher values lead to stiffer wood that can withstand higher loading events (Dahle and Grabosky 2010). $E$ is lower in green wood (moisture content, MC > 30\%-34\%) compared to dried wood that is used as a construction material (Kretschmann 2010). While the relationship between $E$ and moisture and temperature has been well established in wood materials that are below the fiber saturation point (Lavers 1983; Kretschmann 2010; Spatz and Pfiesterer 2013), little is known about how or if $E$ varies in standing trees as they move into dormancy, and if changes in ambient temperature affect $E$. While research has shown MC tends to increase after leaf drop in diffuse hardwood species (Clark and Gibbs 1957), it is unclear if this seasonal shift in MC will result in an increase in $E$ in watersprouts.

Additionally, knowledge on how ambient temperature affects the material properties of wood is based, for the most part, on construction-grade lumber and commercially important tree species. Temperature and availability of precipitation are the main factors that hinder plant performance (Harris et al. 2004). It is understood that material properties of wood increase as temperature and moisture content decrease (below fiber saturation point) (Gerhards 1982), but it is not well understood how temperature impacts material properties of green wood (moisture content $>30 \%$ ).

Understanding how material properties vary in trees will add to the collective knowledge of how trees survive or fail during loading events, such as ice accumulation and snowfall. Models that predict branch failures could help the arboricultural community understand which branches are more prone to failures. Such models would need to include various inputs, including branch allometry, axial and radial variations in material properties, variation in material properties' due to age (maturation), and differences in static and/or dynamic loading due to the presence/absence of leaves. While there is a growing body of knowledge in many of these areas, gaps remain, such as the amount of loading that occurs during storm events; how loads move from branches, down the stem, and into the roots; and how variation in morphology and material properties allow trees to resist failure. The goal of this research was to determine if the modulus of elasticity of juvenile wood varies with temperature (frozen versus warm) and seasonality (pre-dormant versus dormant). This knowledge can help the utility sector better understand if temperature or seasonality leads to watersprouts, and are more likely to undergo larger deflections that could contact energized power lines due to snow or ice accumulation before the leaves have senesced in the autumn.

\section{METHODS AND MATERIALS}

Samples were taken from trees growing at West Virginia University's Research Forest, located in Monongalia County, West Virginia, U.S. The site chosen was a 29.5-hectacre, completed three-stage shelterwood cut. The regrowth trees were all naturally regenerated stump sprouts that can be considered similar to regrowth occurring after storm damage or heading cuts.

A total of 120 northern red oak (Quercus rubra L.) trees were sampled, 60 during the dormant stage, and 60 during the pre-dormant stage. Dormant samples were taken from 01 February through 08 February 2013, while pre-dormant sampling was conducted throughout September 2014. As two growing seasons had elapsed, the pre-dormant sampling targeted sprouts of the same size as the previous dormant sprouts. Only one sprout was harvested from each stump. For each sampling season, 60 sprouts were randomly separated into two equal-sized groups. Thirty of the sprouts were placed at room temperature, estimated at $21.1^{\circ} \mathrm{C}$ (warm), the other half in a CSZ-H/AC environmental unit at $-6.7^{\circ} \mathrm{C}$ (frozen), for five days, respectively. Two pre-dormant sprouts were damaged during handling and were subsequently not tested.

The sprouts were subjected to a three-point bending test with a span of $44.45 \mathrm{~cm}$ using a universal test machine (UTM) (Instron ${ }^{\circledR}$ model MTS 810) at a rate of $0.16 \mathrm{~cm}$ per minute. The warm samples were tested at room temperature $\left(21.1^{\circ} \mathrm{C}\right)$, and the frozen samples were taken from the environmental unit and immediately tested at $-6.7^{\circ} \mathrm{C}$. The samples were not taken to failure during the three-point tests due to high flexibility. The span:depth ratio was selected in accordance to a $14: 1 \mathrm{~cm}$ length to diameter ratio. Force versus deformation (i.e., slope) was obtained from the load cell and cross- 
head movement measurements of the UTM, and was put into the following formula for elasticity:

$$
\text { [1] } \quad E_{S}=\frac{\text { slope } \times \mathrm{L}^{3}}{48 \times \mathrm{I}},(\text { AITC 2012) }
$$

where

$E_{S}=$ flexural modulus of elasticity in gigapascals

$$
\left(\frac{N}{m^{2}}\right) \times 10^{9}
$$

$L=$ the overall test span of the sample (m)

$I=$ moment of inertia of the branch, $\pi \mathrm{r}^{4} / 4$, where the average radius $(r)$ of the overall sample taken at three points, large-end radius, middle radius, and small-end radius $(\mathrm{m})$

Slope $=$ slope of the linear region taken from the force $(n)$ versus deflection $(m)$ curve

Age was calculated for each branch based on visual counting of the growth rings at the proximal end. A disc of wood was cut from each sprout after testing $E$, weighed, oven dried in a lab (Fisher Scientific ${ }^{\mathrm{Tm}}$ Isotemp $^{\text {su }} 500$ series), and then weighed again. Moisture Content (MC) was calculated using the following formula:

$$
M C=\frac{\text { Mass }_{w e t}-M_{a s s_{d r y}}}{M a s s_{d r y}} * 100
$$

where

$M C=$ moisture content

Mass $_{\text {wet }}=$ Mass of disc (grams) at time of testing

Mass $_{d r y}=$ Mass of disc (grams) at oven dry condition

Specific Gravity (SG) was calculated as:

[3] $\quad S G=\frac{\text { Mass }_{\text {dry }}}{\text { Volume } * \rho}$

where

$S G=$ specific gravity

Volume (green) is in $\mathrm{cm}^{3}$

$\rho=1.0 \mathrm{~g} / \mathrm{cm}^{3}$
Difference between the seasons were tested using ANOVA and separation of means using Tukey highest significant difference (HSD). Multiple linear regression (MLR) and simple linear regression (SLR) models were used to examine the relationship between $E$ and all the variables and each individual variable, respectively. In addition, analysis of covariance (ANCOVA) was used to investigate the relationship across different treatments. All analyses were conducted in SAS v9.4 and significance level was set at 0.05 , and all variables and residual were found to be normal.

\section{RESULTS \& DISCUSSION}

A total of 118 stump sprouts were sampled during two different periods-58 pre-dormant and 60 dormant-and the diameter was significantly larger for pre-dormant sprouts than for the dormant sprouts $(P<0.0001$, Table 1$)$. The average $E$ of the stump sprouts was lowest in the pre-dormant warm samples and highest in both the warm and cold dormant samples $(P<0.0001$, Table 1$)$. The pre-dormant cold samples were intermediate in that they did not differ from the other treatments. While there is a slight increase in average $E$ in the dormant sprouts (both warm and cold) it was not statistically different than the pre-dormant cold samples. Hence, it does not appear that the presence of leaves on pre-dormant sprouts impacts the wood stiffness once cold weather is present. This suggests that the sprout stiffness does not differ in these watersprouts as the wood enters dormancy.

A MLR model with the all the potential explanatory variables only found diameter $(P<0.0001)$ as a highly significant predictor of $E$; temperature $(P$ $=0.7454)$, season $(P=0.1832)$, age $(P=0.0688)$, MC $(P=0.1433)$, and SG $(P=0.5747)$ were not significant. While $\mathrm{MC}$, on average, was higher in the dormant wood, neither the MLR model nor a SLR model with only MC as the independent variable supports that MC influences $E(P=0.8286)$. This is not surprising as MC was above $50 \%$ both seasons, and the literature suggests that there is no difference in material properties when MC is above 50\% (Lavers 1983; Kretschmann 2010; Spatz and Pfiesterer 2013). The Forest Products Laboratory's Wood Handbook reports that mature wood has an average SG of 0.65 (Kretschmann 2010), while the juvenile wood of the current study appeared to be 
Table 1. Mean ( \pm SE) diameter, age, moisture content (MC), specific gravity (SG, based on oven-dried and green volume), and flexural modulus of elasticity $(E)$. Sprouts were harvested before leaf drop (pre-dormant) or after leaf drop (dormant) and conditioned at $21.1^{\circ} \mathrm{C}$ (warm) or $-6.7^{\circ} \mathrm{C}$ (cold). Means with the same letter were not significantly different with a Tukey HSD comparison (alpha $=0.05$ ).

\begin{tabular}{llllll}
\hline Treatment & Diameter $(\mathrm{cm})$ & Age & MC $(\%)$ & SG & N \\
\hline Pre-dormant warm & $3.6 \pm 0.06 \mathrm{a}$ & $3.5 \pm 0.10 \mathrm{a}$ & $51.0 \pm 0.35 \mathrm{~b}$ & $0.55 \pm 0.01 \mathrm{c}$ & $1015.6 \pm 49.2 \mathrm{~b}$ \\
Pre-dormant cold & $3.6 \pm 0.06 \mathrm{a}$ & $3.7 \pm 0.08 \mathrm{a}$ & $50.0 \pm 0.35 \mathrm{~b}$ & $0.60 \pm 0.01 \mathrm{~b}$ & $1142.5 \pm 49.7 \mathrm{ab}$ \\
Dormant warm & $3.3 \pm 0.05 \mathrm{~b}$ & $2.9 \pm 0.05 \mathrm{~b}$ & $57.6 \pm 1.16 \mathrm{a}$ & $0.64 \pm 0.01 \mathrm{a}$ & $1214.3 \pm 49.0 \mathrm{a}$ \\
Dormant cold & $3.3 \pm 0.05 \mathrm{~b}$ & $3.0 \pm 0.08 \mathrm{~b}$ & $55.8 \pm 1.25 \mathrm{a}$ & $0.64 \pm 0.01 \mathrm{a}$ & $1290.0 \pm 57.2 \mathrm{a}$ \\
$P$-value & $<0.0001$ & $<0.0001$ & $<0.0001$ & $<0$ & 0.0001 \\
\hline
\end{tabular}

either similar or slightly lower than the mature wood reported in Wood Handbook. Having a higher average SG in the dormant samples could help explain the increase in average $E$. However, the SG does not appear to be a driving factor in the variation in $E$, as it was insignificant in a SLR model between SG and $E(P=0.2997)$ in the juvenile sprouts. While there is a positive correlation between $S G$ and $E$ for wood materials, the non-significant relationship between $S G$ and $E$ in this study may be due to the relatively small variation within the material sampled and the small sample size.

Sprout age $(P<0.0001$, Table 1$)$ was greater for pre-dormant sprouts than the dormant sprouts, yet $E$ did not vary with age $(P=0.6662)$ in a SLR. As the sprouts were most likely completely composed of juvenile wood and it is possible that annual variations in material properties are influencing the results. As diameter was identified as the only significant factor in the MLR model, researchers ran an ANCOVA ( $P$ $<0.0001, \mathrm{~N}=118)$ to determine if diameter could be a covariate with the two treatments. However, the only significant variable was diameter $(P<0.0001)$, while the following variables and covariates were

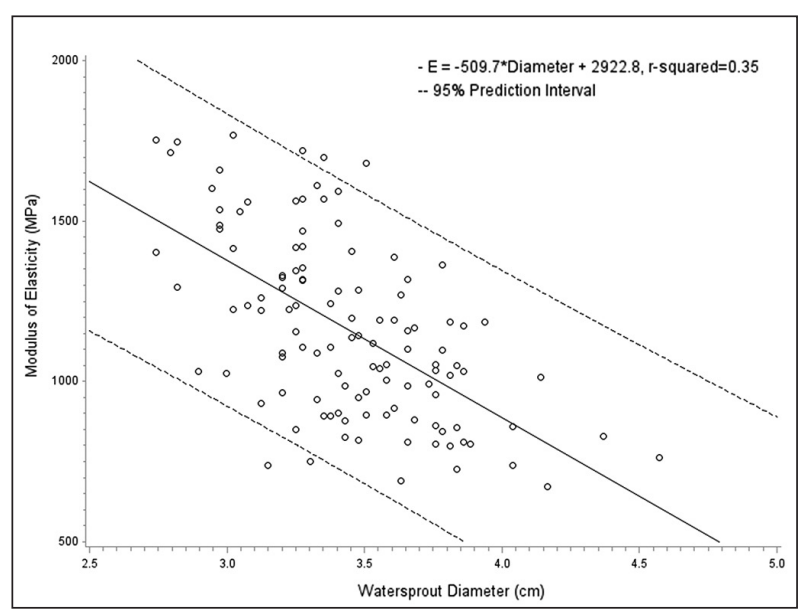

Figure 1. Ordinary least-squared regression between modulus of elasticity $(E, M P a)$ and watersprout diameter. not significant: temperature $(P=-0.5898)$, season $(P=0.7288)$, temperature ${ }^{\star} \operatorname{diameter}(P=0.6811)$, and season ${ }^{\star}$ diameter $(P=0.7780)$. Interestingly, the relationship between $E$ and diameter was negative (Figure 1). It is unclear why $E$ decreases with diameter. It is possible that other factors, such as weather, influenced wood formation that altered $E$, as two growing seasons occurred between the dormant sampling and pre-dormant sampling. While the overall values of $E$ did not vary greatly, researchers may wish to investigate the influence of weather on the material properties of watersprouts.

\section{CONCLUSIONS}

Modulus of elasticity did not vary with temperature in the watersprouts, suggesting that the likelihood of watersprouts bending into energized powerlines does not change with temperature. While dormant sprouts (warm and cold) had higher average flexural elasticity than the warm pre-dormant sprouts, they were not statistically different than the cold pre-dormant sprouts. As such, it does not appear that the flexibility of the watersprouts differs as trees enter dormancy. Surely, the presence of leaves will increase the bending moment, which may lead to an increase deflection of the watersprouts. Yet, in order to ascertain if the difference in $E$ amounts to an appreciable change in failure likelihood, further research is needed to evaluate modulus of rupture and the difference in the interception of loading due to the presence of leaves and the relation to strain concentration in the wood.

Acknowledgments. We would like to thank the U.S. Forest Service for funding this research through a McIntire-Stennis grant (WVA00108) and the Division of Forestry and Natural Resources at West Virginia University. We also thank the anonymous reviewers who provided valuable insight that have improved this manuscript. 


\section{LITERATURE CITED}

American Institute of Timber Construction. 2012. Timber Construction Manual, sixth edition. John Wiley \& Sons, Inc., Hoboken, New Jersey, U.S.

Cannell, M., and J. Morgan. 1989. Branch breakage under snow and ice loads. Tree Physiology 5:307-317.

Clark, J., and R.D. Gibbs. 1957. Studies in tree physiology. IV. Further investigations of seasonal changes in moisture content of certain Canadian forest trees. Canadian Journal of Botany 35:219-253.

Dahle, G.A., H.H. Holt, W.R. Chaney, T.M Whalen, D.L. Cassens, R. Gazo, and R.L. McKenzie. 2006. Branch strength loss implications for silver maple (Acer saccharinum) converted from round-over to V-trims. Arboriculture \& Urban Forestry 32:148-154.

Dahle, G.A., and J.C. Grabosky. 2010. Variation in modulus of elasticity $(E)$ along Acer platanoides L. (Aceraceae) branches. Urban Forestry \& Urban Greening 9:227-233.

Dahle, G., J. Grabosky, B. Kane, J. Miesbauer, W. Peterson, F.W. Telewski, A. Koeser, and G.W. Watson. 2014 Tree Biomechanics: A white paper from the 2010 International Meeting and Research Summit at The Morton Arboretum (Lisle, Illinois, U.S.). Arboriculture \& Urban Forestry 40:309-318.

Field, C., V. Barros, et al. 2014. Climate change 2014: Impacts, adaptation, and vulnerability. Volume I: Global and Sectoral Aspects. Contribution of Working Group II to the Fifth Assessment Report of the Intergovernmental Panel on Climate Change. Cambridge University Press, Cambridge and New York.

Field, C.B., V. Barros, et al. 2012. Managing the Risks of Extreme Events and Disasters to Advance Climate Change Adaptation: Special Report of the Intergovernmental Panel on Climate Change. Cambridge University Press, Cambridge.

Gerhards, C.C. 1982. Effect of moisture content and temperature on the mechanical properties of wood: An analysis of immediate effects. Wood and Fiber Science 141:4-36.

Harris, R.W., J.R. Clark, and N.P. Matheny. 2004. Arboriculture: Integrated management of landscape trees, shrubs, and vines. Prentice-Hall International, Upper Saddle River, New Jersey, U.S.

Hibbeler, R.C. 2005. Mechanics of Material, sixth edition. Pearson Prentice-Hall, Upper Saddle River, New Jersey, U.S.

Kozlowski, T., and S. Pallardy. 1997. Physiology of Woody Plants. Academic Press, San Diego, California, U.S.

Kretschmann, D.E. 2010. Mechanical properties of wood. In Wood Handbook: Wood as an engineering material. General Technical Report FPL-GTR-190. USDA, Forest Products Laboratory, Madison, Wisconsin, U.S.

Lavers, G.M. 1983. The strength properties of timber, third revised edition. London, UK (Department of the Environment, Building Research Establishment). 60 pp.

Spatz H.C., and J. Pfisterer. 2013. Mechanical properties of green wood and their relevance for tree risk assessment. Arboriculture \& Urban Forestry 39:218-225

Valinger, E., L. Lundqvist, B. Sundberg. 1995. Mechanical bending stress applied during dormancy and (or) growth stimulates stem diameter growth of Scots pine seedlings. Canadian Journal of Forest Research 25:886-890.
Gregory Dahle (corresponding author)

School of Natural Resources

West Virginia University

Morgantown, West Virginia 26506-6125, U.S.

gregory.dahle@mail.wvu.edu

Aaron Carpenter

School of Natural Resources

West Virginia University

Morgantown, West Virginia 26506-6125, U.S.

David DeVallance

School of Natural Resources

West Virginia University

Morgantown, West Virginia 26506-6125, U.S.

Mo Zhou

School of Natural Resources

West Virginia University

Morgantown, West Virginia 26506-6125, U.S.

Résumé. Le Panel intergouvernemental sur les changements climatiques affirme avec un haut degré de confiance que les événements climatiques extrêmes présentent des risques élevés pour les services tels les réseaux électriques aériens. Certains de ces événements extrêmes auront vraisemblablement lieu plus tôt en début d'automne, avant que les arbres à feuilles caduques n'aient complété leur processus de mise en dormance et de chute des feuilles. La présence des feuilles durant cette période transitoire - avant la chute des feuilles (pré-dormance) - peut être préoccupante si des chutes hâtives de neige ou de verglas surviennent, à la différence des conditions lorsque la chute des feuilles est complétée et que les végétaux sont en dormance.

Les chercheurs ont récolté des rejets de souches et mesuré le module d'élasticité en flexion $(E)$ du bois afin de déterminer s'il varie avec la saisonnalité (pré dormance versus dormance) et selon la température (gel à $-6,7^{\circ} \mathrm{C}$ versus chaleur à $21,1^{\circ} \mathrm{C}$ ) en utilisant une presse à charge universelle. Bien que les rejets en période de dormance (chauds et froids) présentaient une moyenne d'élasticité en flexion plus élevée que les rejets chauds en pré dormance, ils n'étaient pas statistiquement différents de ceux des rejets froids en pré-dormance. En soi, il ne semble pas que le module d'élasticité diffère lorsque les arbres entrent en dormance. Assurément, la présence de feuilles augmentera le moment de flexion, ce qui peut conduire à une augmentation des bris, mais cette légère augmentation de l'élasticité alors que les arbres entrent en dormance ne devrait pas réduire la probabilité que les gourmands subissent une flexion significative durant une tempête de neige ou de verglas.

Zusammenfassung. Das internationale Gremium für Klimaveränderungen behauptet mit starkem Ausdruck, dass extreme klimatische Ereignisse ein hohes Risiko für Leistungen wie die elektronischen Servive-Netzwerke darstellen. Einige dieser extremen Ereignisse werden wahrscheinlich im Frühherbst stattfinden, bevor die Laubbäume den Prozess zur Winterruhe abgeschlossen haben. Das Vorhandensein von Blättern in einer sich verändernden Jahreszeit - vor dem Blattabwurf (pre-dormant/vor der Ruhe)kann im Vergleich mit nach dem Blattabwurf (dormant/ruhend) problematisch werden, wenn ein unerwarteter Schnee- oder Eissturm auftritt. 
Forscher ernteten Triebe von Baumstubben und maßen den flexuralen Modulus der Elastizität $(E)$ des Holzes mit Hilfe einer universellen Lastpresse, um zu bestimmen, ob es mit der Saisonbedingtheit (pre-dormant versus dormant) und der Temperatur (gefroren $-6,7^{\circ} \mathrm{C}$ versus warm $21,1^{\circ} \mathrm{C}$ ) variiert. Während ruhende Triebe (warm oder kalt) eine größere durchschnittliche flexurale Elastizität als die warmen, noch nicht ruhenden Triebe hatten, waren sie statistisch nicht unterschiedlich als die kalten, noch nicht ruhenden Triebe. Als solches erschien es nicht, dass sich der Modulus der Elastizität verändert, wenn Laubbäume in die Winterruhe gehen. Sicherlich wird das Vorkommen von Blättern den Biegemoment erhöhen, was zu einem stärkeren Versagen führen kann, aber der kleine Anstieg der Elastizität, wenn Bäume in die Winterruhe gehen, sollte nicht die Wahrscheinlichkeit reduzieren, dass Wassertriebe während Schnee- oder Eisstürmen signifikant gebogen werden.

Resumen. El Panel Intergubernamental de Expertos sobre el Cambio Climático establece confiablemente que los eventos climáticos extremos representan un alto riesgo para los servicios como las redes eléctricas. Algunos de los eventos extremos probablemente tendrán lugar antes en otoño, antes que los árboles caducifolios entren en dormancia. La presencia de hojas en una estación de transición-antes de la caída de las hojas (pre-latencia) puede ser motivo de preocupación si ocurre una tormenta intempestiva de nieve o hielo, en comparación con después de la caída de hojas (latencia). Los investigadores recolectaron rebrotes y midieron el módulo de elasticidad $(E)$ de la madera para determinar si varía con la estacionalidad (pre-latente versus latente) y con la temperatura (congelados $-6.7^{\circ} \mathrm{C}$ frente a los $21.1^{\circ} \mathrm{C}$ calientes). Mientras que los brotes latentes (cálidos y fríos) tenían una elasticidad de flexión media más alta que los brotes cálidos pre-dormidos, no fueron estadísticamente diferentes de los brotes fríos pre-dormidos. Como tal, no parece que el módulo de elasticidad difiera a medida que los árboles entran en la latencia. Sin duda, la presencia de hojas aumentará el momento de flexión que puede conducir a un aumento en la falla, pero el ligero aumento de la elasticidad a medida que los árboles entran en la latencia no debería reducir la probabilidad de que los rebrotes experimenten una flexión significativa durante una tormenta de nieve o hielo. 